\title{
Presentació institucional
}

\section{Presentación institucional}

Encara que des de fa algun temps el projecte denominat kult-ur, substanciat ara en la revista i blog del mateix nom, ha anat prenent cos després d'una minuciosa planificació, el fet és que apareix davant dels seus possibles lectors amb l'entrada del nou equip de direcció de la Universitat Jaume I després de les eleccions del passat 20 de maig.

La revista interdisciplinària kult-ur, que suposa un repte per als seus impulsors i col-laboradors, troba el seu nucli al Servei d'Activitats Socioculturals d'aquesta Universitat a través del Programa d'Extensió Universitària (PEU).

Quasi a mitjan segona dècada del segle XXI en què ens trobem, pareix evident la necessitat - una vegada les fronteres entre ciutat i poble quasi s'han diluï- de tornar a pensar el sentit del que suposa tant «poble» com «ciutat», i potser rein-
Aunque desde hace algún tiempo el proyecto denominado kult-ur, sustanciado ahora en la revista y blog del mismo nombre, ha ido tomando cuerpo tras una minuciosa planificación, el hecho es que aparece ante sus posibles lectores con la entrada del nuevo equipo de dirección de la Universitat Jaume I después de las elecciones del pasado 20 de mayo.

La revista interdisciplinaria kult-ur, que supone un reto para sus impulsores y colaboradores, se nuclea en torno del Servicio de Actividades Socioculturales de esta Universidad a través del Programa de Extensión Universitaria (PEU).

Casi a mediados de la segunda década del siglo XXI en que nos hallamos, parece evidente la necesidad - una vez las fronteras entre ciudad y pueblo casi se han diluido- de volver a pensar el sentido de lo que supone tanto «pueblo» como «ciu- 
ventar aquesta última basant-nos en la dissolució de límits d'aquell per a, a continuació, reconsiderar l'estatut que a partir d'ara puguen tenir, comptant $\mathrm{amb}$ nous paràmetres $i \mathrm{amb}$ la reformulació d'altres ja existents. I per això mateix, conceptes com ara sostenibilitat, creativitat, cultura i democràcia, governança i participació, la sempiterna desitjada llibertat, etcètera, van a ser alguns dels ítems que, junt amb altres, sens dubte seran considerats en les argumentacions, intercanvi d'idees i debats que al llarg dels diversos números de la revista aniran eixint.

Inserits en els avatars que propicia la globalització, els aspectes negatius de la qual són no obstant això tinguts per alguns —els poderosos políticament, econòmicament i ideològicament - com la panacea dels nous temps, és així mateix evident que la mobilitat a què la ciutadania de les urbs i la població rural es veuen sotmeses fonamentalment per qüestions econòmiques —amb els subsegüents aspectes com la in crescendo deslocalització d'indústries i serveis-, sense oblidar tota la problemàtica de desplaçats i refugiats, també en augment com a conseqüència dels persistents conflictes existents, fa que el mapa dels punts calents que afecten dad», y quizás reinventar esta última basándonos en la disolución de límites de aquél para, a continuación, reconsiderar el estatuto que a partir de ahora puedan tener, contando con nuevos parámetros y con la reformulación de otros ya existentes. De ahí que conceptos como sostenibilidad, creatividad, cultura y democracia, gobernanza y participación, la sempiterna deseada libertad, etcétera, vayan a ser algunos de los ítems que, junto a otros, sin duda serán considerados en las argumentaciones, intercambio de ideas y debates que a lo largo de los diversos números de la revista irán saliendo.

Insertos en los avatares que propicia la globalización, cuyos aspectos negativos son sin embargo tenidos por algunos - los poderosos política, económica e ideológicamente - como la panacea de los nuevos tiempos, es asimismo evidente que la movilidad a que la ciudadanía de las urbes y la población rural se ven sometidas fundamentalmente por cuestiones económicas - con los subsiguientes aspectos como la in crescendo deslocalización de industrias y servicios-, sin olvidar toda la problemática de desplazados y refugiados, también en aumento como consecuencia de 
la problemàtica humana en el més extens sentit de la paraula, disten molt de ser aplacats en benefici real de les persones.

És per això que els promotors de kult-ur entenen que el binomi «increment de riquesa per a uns» - «exclusió del benestar econòmic i social per a altres» siga quelcom èticament i humanament inadmissible. I per tant estiguen disposats, des de la seua talaia crítica, a esmicolar analíticament tots els elements, processos i ressorts que intervenen en aquesta endiablada maquinària d'índole social, i presentar — des d'aquest estudi- algunes conclusions que conduïsquen en la mesura que siga possible a proposar determinades solucions que propicien la instauració d'un món més humà, solidari i just. Quelcom que necessita, com a punt o base de partida, la plena presa de consciència de la situació $i$ apostar personalment per això per mitjà del compromís social.

Doncs bé, des de la tasca de construcció de l'ésser humà assagetada cap al món de la Lebenswelt, tenint en compte per descomptat la Weltanschauung com a conjunt d'opinions que conformen el concepte general del món que es té en una època $i$ los persistentes conflictos existentes, hace que el mapa de los puntos calientes que afectan a la problemática humana en el más extenso sentido de la palabra, disten mucho de ser aplacados en beneficio real de las personas.

Es por eso que los promotores de kult-ur entienden que el binomio «incremento de riqueza para unos» - «exclusión del bienestar económico y social para otros» sea algo ética y humanamente inadmisible. Y por ende estén dispuestos, desde su atalaya crítica, a desmenuzar analíticamente todos los elementos, procesos y resortes que intervienen en esta endiablada maquinaria de índole social, y presentar — desde ese estudio - algunas conclusiones que conduzcan en la medida de lo posible a proponer determinadas soluciones que propicien la instauración de un mundo más humano, solidario y justo. Algo para lo cual es necesario, como punto o base de partida, la plena toma de conciencia de la situación y el apostar personalmente por ello mediante el compromiso social.

Pues bien, desde la tarea de construcción del ser humano flechada hacia el mundo de la Lebenswelt, teniendo en cuenta por supuesto la 
cultura, és des d'on d'alguna manera podem emplaçar la base epistemològica que s'ha de desenvolupar per mitjà d'aquest projecte.

Wenceslao Rambla Zaragozá

Vicerector de Cultura, Extensió Universitària i Relacions Institucionals. UNIVERSITAT JAUME I
Weltanschauung como conjunto de opiniones que conforman el concepto general del mundo que se tiene en una época y cultura, es desde donde de alguna manera podemos emplazar la base epistemológica a desarrollar mediante este proyecto.

\section{Wenceslao Rambla Zaragozá}

Vicerrector de Cultura, Extensión Universitaria y Relaciones Institucionales. UNIVERSITAT JAUME I 